\title{
The Implications of Religious Tolerance and Nationalism Values at Islamic Boarding School
}

\author{
Nicky Estu Putu Muchtar 1, Imam Suprayogo 2, Triyo Supriyatno 3 \\ DOI: $10.35445 /$ alishlah.v13i3.705
}

Article Info Abstract

Keywords:

Nationalism,

Religious Tolerance,

Value Implication

Kata kunci:

Nasionalisme,

Toleransi Beragama, Implikasi Nilai
The purpose of this study was to understand how is the implication of religious tolerance and nationalism values applied by each islamic boarding school. This study was conducted in Islamic boarding schools in Lamongan, which were: IBS of Islam Al-Islam, IBS of Karangasem Muhammadiyah, IBS of Sunan Drajat, and IBS of Modern Muhammadiyah. This study applied a qualitative method, interpreted with a phenomenology approach. The techniques of data collection were through observation, interview and documentation. The results of the study showed the implication of religious tolerance in IBS of Islam Al-Islam, IBS of Karangasem Muhammadiyah, IBS of Sunan Drajat, and IBS of Modern Muhammadiyah possessed the values of acceptance, respect, patience, freedom and cooperation. Meanwhile, differences were found dealing with nationalism values. The IBS of Islam Al-Islam merely possessed the value of respect, though IBS of Sunan Drajat, IBS of Karangasem Muhammadiyah, and IBS of Modern Muhammadiyah possessed the values of self-sacrifice, unity, respect, cooperation, and value of pride of being nation. The findings of this study also led to understanding and implementing the values taught through the spirit of jihad for religion and nation, which was based on the concept of 'Jihad Kebhinekaan' synergizing between theories and research findings.

\begin{abstract}
Abstrak
Tujuan dari penelitian ini adalah untuk memahami bagaimana implikasi nilainilai toleransi beragama dan nasionalismenya yang diterapkan masing-masing pesantren. Penelitian ini dilakukan di Ponpes Lamongan meliputi; Ponpes Islam Al-Islam, Ponpes Karangasem Muhammadiyah, Ponpes Sunan Drajat dan Ponpes Modern Muhammadiyah. Penelitian ini menggunakan metode kualitatif yang diinterpretasikan dengan pendekatan fenomenologi. Teknik pengumpulan data melalui observasi, wawancara dan dokumentasi. Hasil penelitian menunjukkan bahwa implikasi nilai-nilai toleransi beragama di keempat Ponpes mempunyai nilai menerima, menghargai, kesabaran, kebebasan dan kerjasama. Dan nilai-nilai nasionalisme terdapat perbedaan nilai yang diajarkan Ponpes Islam Al-Islam mempunyai nilai harga menghargai saja terkait nasionalisme. Berbeda dengan Ponpes Sunan Drajat, Ponpes Karangasem Muhammadiyah, dan Ponpes Modern Muhammadiyah yang mempunyai nilai rela berkorban, nilai persatuan \& kesatuan, nilai harga menghargai, nilai kerja sama, dan nilai bangga menjadi bangsa Indonesia. Hasil temuan penelitian ini juga memunculkan pemahaman serta mengimplementasikan nilai yang telah diajarkan melalui semangat berjihad
\end{abstract}

${ }^{1}$ Universitas Islam Lamongan, Indonesia

Email: nickyestu93@gmail.com

2 Universitas Islam Negeri Malang, Indonesia Email: profimam@yahoo.com

3 Universitas Islam Negeri Malang, Indonesia

Email: triyo@pai.uin-malang.ac.id

Vol.13 (3) December, 2021

Received: June 26, 2021; Received in revised form: July 28, 2021; Accepted: August 9, 2021; Available online: December 31, 2021. This is an open access article under a Creative Commons Attribution-NonCommercial-ShareAlike 4.0 International License. 

bersinergi antara teori dan temuan penelitian.

\section{INTRODUCTION}

Value denotes an important effort in education (Mulyana, 2011a), mainly at Islamic Boarding Schools. Etymologically Value is also defined as the most important thing in human's life (Nurkholis, 2013) However, Mulyana (Mulyana, 2011b) argued that value is trustworthy and is represented as a model in making a choice. Meanwhile, value denotes a standard in determining the whole things (norms) (Zakiyah \& Rusdiana, 2014a). In addition, value is a conception (Zakiyah \& Rusdiana, 2014b) (either implicit or explicit that distinguishes an individual or group characteristics) of what is desired, that influences choice against manner, actions of in-between and final goals. Value is also defined as an idea and concept of human's thoughts that are considered important. With value, humans can determine which is good and bad (Jempa, 2018), also can determine the steps of thinking.

Islamic Boarding School [henceforth (IBS)] becomes the agent of change for Muslims, that the Muslim religious teachers' [henceforth (Kyai/pengasuh)] doctrine of teaching values will shape Islamic students' [henceforth (santri)] character. The Islamic Boarding School can also mediate all issues existing in the society (for example, issues related to intolerance, terrorism, violent acts and so on). The religious tolerance and nationalism values taught in the Islamic Boarding School have an important role to realize the state with integrity, loving peace and rising unity. The Islamic Boarding School is a place to create a generation that upholds Islamic teachings, it is with guidance from the Ulama'/Kyai and the santri as examples in the society. Without them, the Muslim society may lose direction.

Islamic Boarding Schools in Lamongan have various principles of life values taught to the santri, particularly those among each IBS about religious tolerance and nationalism values. This study is conducted in four Islamic boarding schools in Paciran District, Lamongan Regency that has different affiliations. Through teaching and various activities denotes the efforts of the IBS to embed religious tolerance and pride of being nation values for the sake of the next generation of Muslims with conveying goodness and peace for the nation. Here are previous studies that revealed the embedment of religious tolerance and nationalism values in several IBS; First, (Prasetyo \& Sumardjoko, 2017), The Embedment of Nationalism Values in IBS of Khalafiyah (A Case Study at IBS of Al Huda Candigatak Cepogo Boyolali 2016). The results of this study found that the embedment of nationalism value to the santri was through formal education and religious activities. Second, (Rois, 2017), The Embedment of Nationalism Value within the Education at IBS of Miftahul Ulum Eastern Ungaran Semarang Regency, the study concluded that the embedment of nationalism value in IBS of Miftahul Ulum Ungaran was through activities reading holy books [henceforth (kitab)] and daily activities such as cooperation, and so on. The factors of fruitfulness and obstacles were concluded to rely on teachers, IBS managers with facilities and santri's self-motivation. Third, (Mustofa, 2019) entitled 'Educational Values in IBS (A Study of Pancajiwa Internalization at IBS of Modern Darussalam Gontor Ponorogo)' discussed educational value that found a value indicating a sense of tolerance and nationalists in the of value ukhuwah implemented.

It is noteworthy that this study focuses on IBS with different affiliations and cultural characteristics: First, Islam Al-Islam, which is affiliated with Salafi Jihadi and has been used as a research object for radicalism and terrorism (Sholikin, 2018); Second, Karangasem Muhammadiyah, which is affiliated with the Islamic Society of Indonesia; and T, which is affiliated with the Indonesian Muslim Brotherhood. Each of the four IBS can be studied as a benchmark for how religious tolerance and nationalist values are implemented by each IBS. 


\section{METHOD}

This study was conducted to obtain complete and detailed data through a qualitative approach (Sugiyono, 2016). The qualitative approach was selected in this study due to being capable of describing and understanding the fundamental meaning of the behaviour of the informant, describing backgrounds and various interactions, and exploration that was done to identify various types of information and phenomena. In this qualitative study, the phenomenology approach was applied. Because phenomenology is a truth that is obtained by capturing the phenomenon of substances or signs from the object investigated (Arikunto, 2005). While, the data collection techniques were through observations, interviews and documentation. The results of the technique of data collection were through data obtained analysis, data condensation, data grouping and verification. Furthermore, the validity of the findings used a focus group discussion (FGD) to test the validity of the research data.

\section{FINDINGS AND DISCUSSION}

\section{Implications of Religious Tolerance Values}

Acceptance Value

The manifestation of a tolerance statement is accepting any things that are different from ourselves (Rachman, 2004). This acceptance of each group is based on a high awareness without looking at shortcomings, advantages and does not compare or take into account the good and the bad. Accepting everything that has already existed becomes sunnatullah. This had been exemplified by the Prophet Muhammad SAW, at that time, who was willing to accept differences among Madinah society, which was later known as the 'Madinah Charter' (Rachman, 2010). This Madinah Charter united the differences among Madinah society that conflicted (Ismail, 2014) at that time for the sake of living in peace and helping each other.

Thus, the results of this study; First, the implications shown in the acceptance value were that the researcher was allowed to research the four Islamic boarding schools (IBS of Islam Al-Islam, IBS of Karangasem, IBS of Sunan Drajat, IBS of Modern Muhammaddiyyah), and the IBS were open to discussing together regardless of the researcher's background. The acceptance was not only shown by the Kyai, but also the santri's friendliness for allowing them to join their activities and being willing to conduct interviews and observations. There were openness and acceptance between the researcher and the IBS's side. Second, acceptance with the foreign or other religions. In this case, there were differences among each IBS. The IBS of Islam Al-Islam is still closed to foreign and very restrictive. The IBS of Karangasem and Modern Muhammaddiyah accept differences and are open to anyone, even the foreign or non-Muslims. However, there has never been intense cooperation and still limits the way to be tolerant except the Muslim.

This is different from the IBS of Drajat's acceptance to the foreign and non-Muslims, not only on the concept but also in the implementation of tolerance (for instance, by working together and accepting the foreign openly). In other words; the acceptance of tolerance by the IBS of Sunan Drajat is not only to the Muslims but also the non-Muslims. In the moment of the Bali Bombings 2002, not only IBS of Islam Al-Islam become the attention of the foreign, but also other IBS in Paciran were targeted by Australian intelligence at that time. The IBS of Sunan Drajat is known and labelled for being high tolerance for non-Muslims that researchers from Australia, at that time, assigned to observe some conditions of IBS in Paciran, they preferred to stay at IBS of Sunan Drajat. And the IBS of Sunan Drajat accepted it openly. The IBS of Sunan Drajat has also held an FKUB (Forum for Religious Harmony) with the theme "Different but Friendly". One of the documentation is in the appendix. The tolerance shown by the IBS of Sunan Drajat illustrated the importance of religious harmony and creating peace in Indonesia (Hasan, personal communication, August 4, 2020). 


\section{Respect}

Respect is being kind to others by not reducing their right to be principled. (Kurnia, 2011) In addition, Rusnali argued that respect is not only reverencing beliefs recognized by the state but also those that are not recognized by the state, we must keep accepting (Ruslani, 2000). The IBS of Islam Al-Islam, Karangasem, Sunan Drajat and Muhammaddiyah have values of respect. In this case, it was shown by the view of tolerance according to each IBS as in the previous explanation at point B related to the view of tolerance. It can be concluded that they realize Indonesia is a plural society, meaning that various understandings may occur among different groups. And, Al - Qur'an also explains that once there are differences, the attitude taken is to respect without hurting or following other religion's worship, as in Surah Al-Kafirun verses 1-6.

\section{Patience}

Etymologically, patience comes from Arabic, șabara, "șabara" which means to restrain (alhabs). According to Louis Ma'luf, he elaborated the word aș-șabr based on the word (letter) that follows. If the word sabara is followed by the letter ala shabr, it means steadfast. If it is accompanied by the letter an shabr, it means to restrain and keep oneself from doing, and if followed by bi shabr, it means to maintain (Nawawi, 2011). According to Imam Al-Ghazali, patience is to refrain from any bad deeds and prefer to everything that is pleased by Allah SWT (Ghofur, 2005). If it is correlated with tolerance so that social humans can be sympathetic to accept all differences related to opinions and principles of faith without criticizing others. Likewise, Khisbiyah said patience intolerance is that every human can restrain themselves to anything that they do not agree with or dislike to foster harmonious relationships as social beings (Khisbiyah, 2007).

Sometimes humans are too selfish and feeling always right. However, when we socialize in the society or colleagues in the environment, the patience or to refrain from anything that don't agree with or don't like to and without criticizing others is a form of tolerance among others. The results of the study related to the value of patience, the IBS of Karangasem, Sunan Drajat, and Modern Muhammaddiyyah were found no problems in terms of the value of patience. This means that this patience is still limited to accepting and respecting others and not doing anarchy to others or the non-Muslim. On the other hand, although being rumoured to be radical, hard-liners due to the alumni of IBS of Islam Al-Islam Paciran and other schools have been in contact with the JI organization (Jamaah Islamiyah), (Sholikin, 2018) yet the recent condition if taking a look at the side of patience, their attitude taken is to be silent (Imron, personal communication, August 8, 2020a). Because according to Ustadz Ali Imron and Ustadz Khozin, some santri still have radical or anti-Pancasila thoughts. This silence is a form of the value of patience, even though they do not agree with the 1945 Constitution and Pancasila. Tolerance for them is indeed mutual respect, but their principle of legal law prefers Sharia's law made by Allah SWT which is in accordance with Al - Qur'an.

\section{Freedom}

Freedom or al-hurriyah in Islam originates from 'ikhtiyar' and 'taqdir', where the way of freedom becomes the own personal responsibility in behaving whether wishing to do it or not, in the theology of religious reasoning (In'amuzzahidin, 2017). Furthermore, in the process of its development, freedom includes democracy, politics and the economy. In line with Budhi explained that one who have a will and do it according to their wishes are called freedom. And the freedom that comes from ones themselves, they are also accountable for (Rachman, 2012).

There are various kinds of freedom in Islam, namely; freedom of belief, freedom of spirit, freedom of thought, freedom of residence, freedom of ownership, and freedom of learning. Islam maintains peace and encourages mutual respect so that there is no separation, enmity and hatred between human beings because Islam frees to follow religious beliefs (Rachman, 2015). Allah SWT has said in surah al-Kafirun verse 6 that there is no compulsion to adhere to respective religions and 
let the humans choose a religion that is considered correct and carry out according to their respective teachings without forcing or hindering others dealing with the beliefs (Baidi, 2012).

Based on the interviews with each IBS, the value of freedom was concluded all based on Surah Al-Kafirun verses 1-6, that Islam does not force others to convert to Islam, and vice versa. And the difference is a part of sunnahtullah that cannot be avoided. To create harmony, each IBS agrees on a tolerant life. From the research results, a common view of freedom according to IBS of Islam AlIslam, Karangasem Muhammadiyah and Modern Muhammadiyah was that freedom of religious tolerance must have limits. For example, allowing the non-Muslims to celebrate worship, but the Muslims are not allowed to say 'Merry Christmas' or help their worship. Meanwhile, IBS of Sunan Drajat's opinion was that no problem to say 'Merry Christmas', as long as not following the worship performed by non-Muslims.

\section{Cooperation}

Cooperation arises from the existence of a vertical relationship between the adherents and God. In addition, it also covers all acts of worship and things of good value, such as cooperation that will lead to other aspects of the inter-religious relationship. Help and support for other people having different beliefs will create cooperation in religious tolerance. When each individual can tolerate each other, not only mutual respect but also mutual cooperation, a safe and cool atmosphere can occur properly. It certainly proves how one relates to others, and that it can create a humanist society (Rini, 2019).

Within the scope of the IBS (IBS of Islam Al-Islam, Karangasem, Sunan Drajat and Modern Muhammaddiyah), the santri have been embedded to work together, using ro'an or mutual cooperation. Each of IBS do the same time, which is every Friday. Within the scope of society, IBS of Karangasem Muhammaddiyah and IBS of Modern Muhammaddiyah cooperate with both local's and the city's society for da'wah programs. It is by sending the santri to perform religious syi'ar in several areas, teach Al - Qur'an and preach of Jum'at in Paciran society's mosque every Ramadan month. These two IBS have similarities in terms of collaboration with the society involving their santri through becoming cadre of muballigh. Regardless of the santri's background, the society is willing to accept and provide opportunities for the santri to learn, also the society is also helped by the presence of the santri in preaching. So that students can also learn to live tolerantly in society.

Meanwhile, at IBS of Sunan Drajat, the cooperation is carried out with the society or the nonMuslims relating to the economy. The IBS has several businesses, and the santri participate in the work of the business by collaborating with several parties. So that the santri also have the skills to work and create a job after being in IBS. The IBS of Sunan Drajat has a high tolerance for nonMuslims. The efforts to develop the economy among IBS to educate and equip the santri to be financially independent in the future are the reasons for collaborating with anyone regardless of religion. The santri are expected not only to have religious knowledge but also to be successful in the economic field and able to compete with the changing modern times, science and technology.

\section{Implications of Nationalism Values}

Value is something that every human being likes and always wants, is aspired and is agreed which is considered very important and valuable (Moeljono, 1989a). And nationalism values are those originating from the soul and spirit of the Indonesian which are expected to be a benchmark in every behavior for the sake of society, nation and state. The nationalism values are as follows: Value of self-sacrifice

The value of self-sacrifice is an enthusiastic act to defend the nation and state. The act of selfsacrifice with soul, body, and property in defending the nation without wanting anything in return is a form of loving the country. It is found in Surah Al-Anfal verse 60:

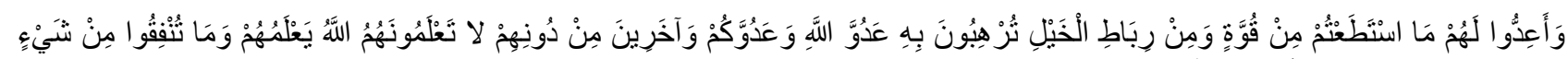

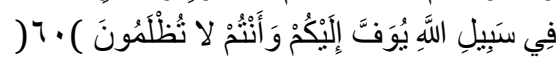


Meaning: 6o. "Against them make ready your strength to the utmost of your power, including steeds of war, to strike terror into (the hearts of) the enemies, of Allah and your enemies, and others besides, whom ye may not know, but whom Allah doth know. Whatever ye shall spend in the cause of Allah, shall be repaid unto you, and ye shall not be treated unjustly." (Departemen Agama RI, 1989b) QS. Al-anfal verse 60

In the verse above, self-sacrifice means being brave and full of enthusiasm in the war against the invaders in order to protect the country from enemies, not only through physical but also through giving wealth in the way of Allah. While in education, the value of self-sacrifice is obtained from various subjects in schools and IBS. The santri should not only learn, but also implement in an action, for example; helping a friend in need, willing to do anything to help the friend hit by disaster. Also, performing rights and obligations as to be the good Indonesian people, and becoming student/santri with performing obligations and not violating the rules in schools or IBS.

From the results of this study, the value of self-sacrifice creates the concept of jihad in the view of each IBS. Because the state and religion cannot be separated, considering that Muslims is the majority in Indonesia, Islam also teaches jihad to defend religion, nation and state for the sake of a peaceful life. Each IBS has a different statement, but the value of self-sacrifice principally is interpreted into 'jihad', that is being serious in goodness and defending religion and state. The meaning of jihad to defend religion according to IBS of Islam Al-Islam and Karangasem is 'war', so when Islam is fought, the Muslims are obliged to fight against the enemy. However, if the current Indonesian conditions are still considered safe even though there are injustices against Muslims, IBS of Karangasem Muhammadiyah decides to discuss first, provide input to the government and so on. Once, the Muslims are experiencing a crisis or attack, the IBS of Karangasem Muhammadiyah obliges them to carry out jihad. While the IBS of Islam Al-Islam gave an example of when the Muslims were killed and treated inhumanely as in Poso. For IBS of Islam Al-Islam, Poso was a place of jihad to fight the injustices committed by non-Muslim at that time. (Imron, personal communication, August 8, 2020a) On the other hand, as Ustadz Ali Imran's explanation states that the current condition in Indonesia is undergoing attack from other countries, then jihad to defend is also obligatory. The strong principles in building the value of self-sacrifice were by interpreting 'jihad' and implementing it towards religion and state.

In contrast, when experiencing injustice and being fought, the IBS of Sunan Drajat preferred applying educational strategies and placing the Muslims as leaders or so on to reduce the injustice. And IBS of Modern Muhammaddiyah explained that defending the sovereignty of the Republic of Indonesia from threats within and outside the country is jihad.

\section{Value of unity}

Everything created by Allah SWT will always have two sides, there are male and female. And His creation has become sunnahtullah that humans are created differently across ethnic, religions, races, cultures, and groups. In IBS, embedding the value of unity is very important to provide insight that even though differences exist, the attitude taken is to maintain harmony and love, so that the unity of the nation is realized into a developed, peaceful and solid country.

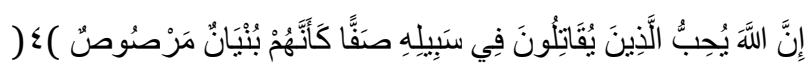

Meaning: 4. "Truly Allah loves those who fight in His Cause in battle array as if they were a solid cemented structure." (Imron, (Imron, personal communication, August 8, 2020c) QS. As Shaff verse 4

In Surah As-Shaff verse 4, if it is linked to the value of unity, once Indonesia is united, it becomes strong, is not easily divided by political interests or a few groups who want to damage 
among nations, and so on so that peace cannot be established. In the context of IBS's education, it is implemented in forms of student organization activities, hizbul wathan, martial-art extracurricular, and certainly a national insight which is summarized informal learning and IBS.

The value of unity is actualized in the forms of cooperation and organizational activities. The organizations at IBS of Islam Al-Islam are not very visible in a structured way, but OSIS exists. Organizations in IBS of Karangasem are carried out structurally and organized, both schools and universities including IPM (Muhammadiyah Student Association), HW (Hizbul Wathan), Tapak Suci, OPPKM (Student's Organization of IBS of Karangasem Muhammaddiyah), and IMM (Islamic Student Association).

Organization as a leadership activity for the santri at IBS of Sunan Drajat, at the level of SMP (Junior High School) and SMK (Vocational High School), uses the term OSIS, while MTs (Islamic Junior High School) and MA (Islamic Senior High School) use the term IPNU-IPPNU, and MMA (Madrasah Mu'allimin Mu'allimat) uses the term JT (Jamiyah At Thulab). Meanwhile, the organization as a cadre forum to train the leadership spirit at IBS of Modern Muhammaddiyah includes; Muhammaddiyah Student Association (IPM), Women's IBS Organization (OPP PMMP), Men's IBS Organization, Muhammadiyah Student Association, and Paciran Modern Muhammadiyah Alumni Association. First, cooperation is a part of the third principle, namely 'Unity of Indonesian'. Once the value of unity disappears, cooperation impossibly occurs. And second, the organization is able to regenerate a generation with a broad national perspective and create a generation with good morals by sticking to the truth.

\section{Value of respect}

The value of respect refers to an act of appreciating each other. A respect act in religion denotes not allowing to insult or vilify anything done by other religions. As in His word;

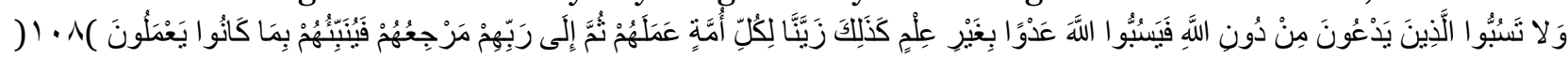

Meaning: 108. Revile not ye those whom they call upon besides Allah, lest they out of spite revile Allah in their ignorance. Thus have We made alluring to each people its doings. In the end, will they return to their Lord, and We shall then tell them the truth of all that they did. (Imron, personal communication, August 8, 2020d) QS: Al-An'am verse 108

Islam is the perfect religion for all mankind. Islam teaches to respect other religions, even though other religions are not those that are blessed by Allah SWT. The act of being a good Muslim is by respecting other people's beliefs without hurting them and accepting their presence in society. To implement the value of respect, the santri carry out several activities, such as mutual cooperation/ro'an, through various extracurricular activities, learning, deliberating when organizing and so on.

\section{Value of cooperation}

The value of cooperation is in the forms of cooperation and assistance based on the spirit of kinship. Cooperation is only carried out in goodness, not acts that violate Islamic law or other bad deeds. Having cooperation to violate Islamic law is not justified as in the above verse. Cooperation in goodness is in the form of an act of inviting others to do goodness and to avoid falseness or evil things. As Surah Al Imran verse 104 explained;

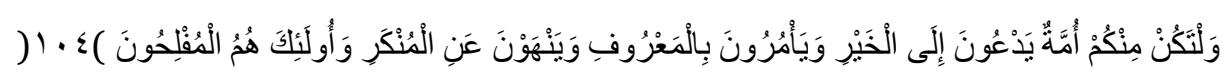

Meaning: 104. "Let there arise out of you a band of people inviting to all that is good, enjoining what is right, and forbidding what is wrong: They are the ones to attain felicity." (Imron, personal communication, August 8, 2020f) QS. Al Imran verse 104 
Surah Al Imran verse 104 also explains that ma'ruf acts will draw closer to Allah SWT, instead Munkar acts will keep one away from Allah SWT. In IBS activities, cooperation is done anywhere and anytime which is a daily habit through mutual cooperation, mutual assistance among friends in needs, group work in learning, teamwork in organizations, helping people affected by disasters and other social activities. Cooperation is not only done among santri at IBS but they are involved in collaborating with non-Muslims, as also a part of the learning process of respect as in IBS of Sunan Drajat.

The implications of this value can be seen from the act of cooperation activities done by the santri, as IBS of Karangasem and Modern Muhammaddiyah collaborating with the society in the activity of muballigh cadre, and IBS of Sunan Drajat that collaborates in the economic sector regardless of religions. Cooperation keeps taking place.

This cooperation is done to maintain good relations among others, to be able to interact socially, to exchange ideas and experiences, to support each other so that Muslims development in any fields grows quite rapidly, to train self-confidence, to deliberate, to ease jobs, and to achieve consensus goals for the sake of common interest. The value of cooperation can also be actualized in organizational activities. By participating in organizations, the santri are able to train collaboration between teams, make decisions by deliberating, and increase good relations among members or even expand outside networks.

\section{Value of pride of being Indonesian}

The value of pride in being Indonesian refers to a sense of loving the homeland, a sense of pride to be a part of the Indonesian nation. One who is proud of being Indonesian will always uphold justice in Indonesia. Dealing with this, Allah Almighty says;

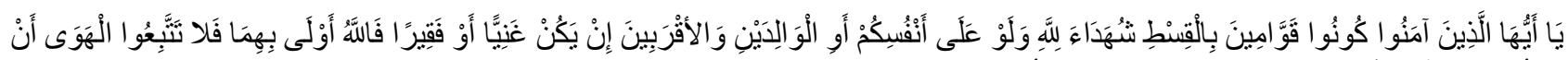

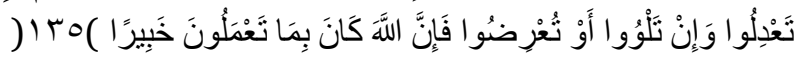

Meaning: 135. "O ye who believe! stand out firmly for justice, as witnesses to Allah, even as against yourselves, or your parents, or your kin, and whether it be (against) rich or poor: for Allah can best protect both. Follow not the lusts (of your hearts), lest ye swerve, and if ye distort (justice) or decline to do justice, verily Allah is well- acquainted with all that ye do." (Departemen Agama RI, 1989c) QS. An-Nisa' verse 135

Proud of being a part of Indonesian, besides upholding justice as stated in the above verse, loving and preserving Indonesian culture is a value of pride of being Indonesian (for example, activities done by the santri through preserving music, cultural arts organized by the school to show the talents). With a sense of pride, they are also able to compete in competitions both national and international competitions. In a sense, that; Indonesia can have to competent generation, highly dedicated, and qualified Human Resources.

Proud of being Indonesian also means being the pride of self-potential and loving the nation's culture. This can be done through extracurricular activities, in addition to developing talents and potentials, the santri can also utilize well science and technology to facilitate social community relations and can compete in terms of achievements based on the fields.

At IBS of Karangasem, there are 2 optional extracurricular that the santri can select: they are extracurricular at IBS and extracurricular at school. The extracurricular at IBS that the santri can select according to talents and interests includes; Qiro'ah, Tapak Suci, Infokum Literacy, Infokum Media, Knitting Skills, Basketball, Volley, and Badminton. While extracurricular at school includes; Religious Music Group, Robotics, Volley Ball, Futsal and Football, Badminton, Table Tennis, Recitations, Calligraphy, Entrepreneurship, Graphic Design, and ten-finger typing. 
At IBS of Sunan Drajat, several formal institutions have extracurricular activities, which are pencak silat, volleyball, tambourine, qiro'ah, lion-dance, tongklek, karawatin, angklung, PMR, football, theatre, scouts and so on. Meanwhile, at IBS of Modern Muhammaddiyah, the extracurricular activities include; Scouting, Hizbul Wathan, Sports (Futsal, Volley, Basketball, Badminton), Tapak Suci, Catering, Screen-Printing, Journalism, and Traditional Arts. Through these extracurricular activities, the santri can develop their talents and show their achievements in national and international competitions. In a sense that; Self-pride may emerge when Indonesia is known due to its achievements.

\section{The Implications of Religious Tolerance and Nationalism Values at Lamongan Islamic Boarding School}

In every human's life, there are various values. Different points of view of ones' values determine attitudes and behaviour in daily life. The figure of the leader or Kyai at IBS becomes a role model for the santri and the society to foster values taught because the aspect of religion or belief is very important and influential towards the doctrine of values. The religious tolerance values are taught to the santri to understand that differences are sunnahtullah, so that not blaming each other and creating peace take place amid society with diversity. Meanwhile, the nationalism values are taught to the santri that living in Indonesia is with the love of the diversity of tribes, religions, cultures, customs, cultures, races and groups into one unit of 'Bhineka Tunggal Ika' in advancing the nation and state according to the field they are engaged. Once the santri are taught religious tolerance and nationalism values, then socializing in the society can bring goodness and peace, after graduating from the IBS.

Here is the picture of the implications of religious tolerance and nationalism values at Lamongan Islamic Boarding School (including IBS of Islam Al-Islam, IBS of Karangasem Muhammadiyah, IBS of Sunan Drajat and IBS of Modern Muhammadiyah):

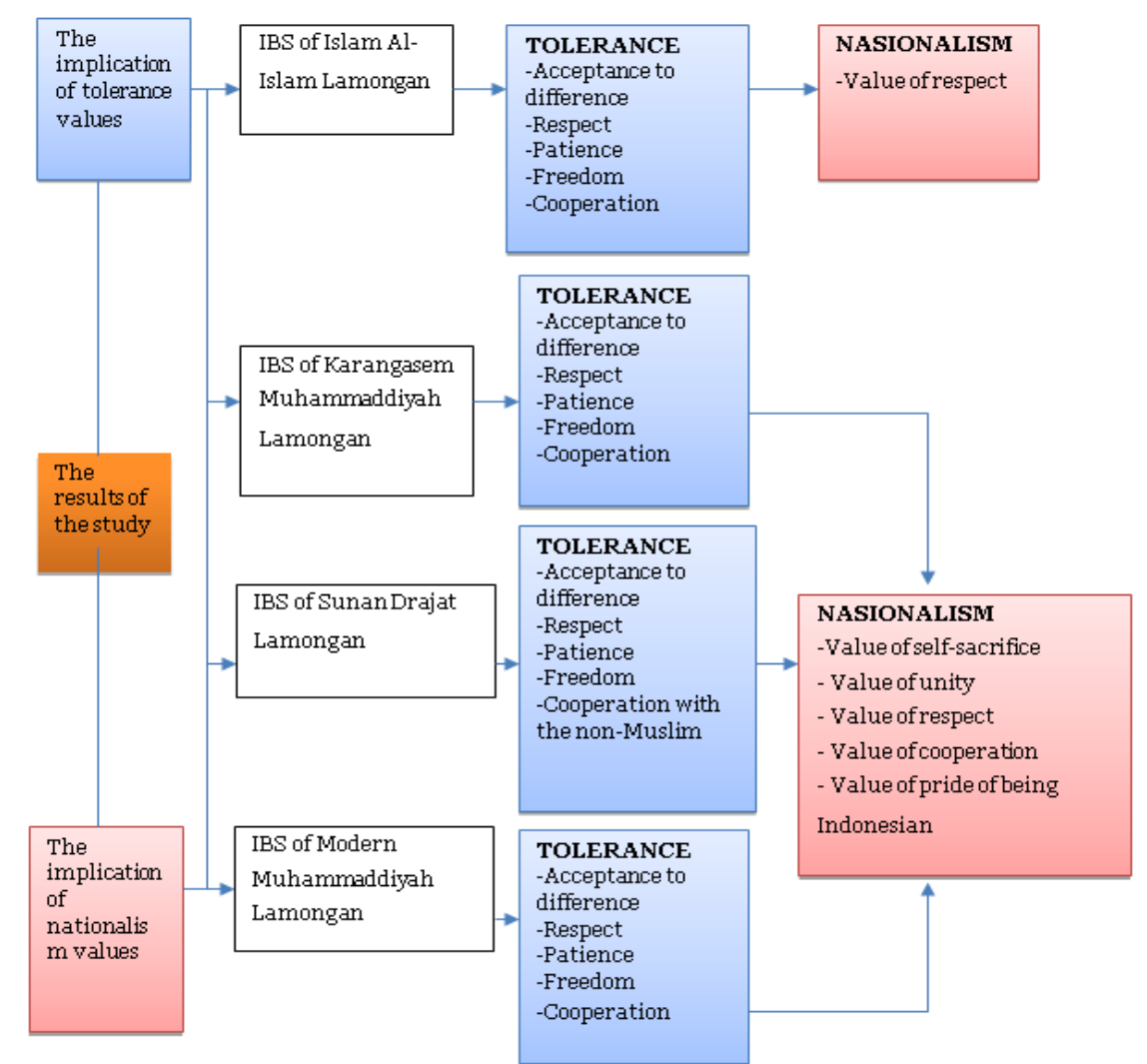

Figure 1. The picture of the Implication of Religious Tolerance and Nationalism Values at Lamongan Islamic Boarding School 
The picture above explains similarities and differences in the four IBS respectively. The educational implications of religious tolerance values at IBS of Islam Al-Islam, IBS of Karangasem Muhammadiyah, and IBS of Modern Muhammadiyah possess values of acceptance, respect, patience, freedom and cooperation (amongst Muslims). Meanwhile, the IBS of Sunan Drajat possesses values of acceptance, respect, patience, freedom and cooperation. The collaboration done by IBS of Sunan Drajat is through economy business, where the santri are involved to work in the economic sector collaborating with the non-Muslim entrepreneurs. (Hasan, personal communication, August 4, 2020) Meanwhile, differences are found dealing with nationalism values, where IBS of Islam Al-Islam merely possesses a value of respect. This is due to an understanding that does not approve the existence of the 1945 Constitution made by humans as the basis of the state or anti-Pancasila. However, there have been major changes in the radicalization process in the recent 4-5 years. (Imron, personal communication, August 8,2020a) In contrast, IBS of Sunan Drajat, IBS of Karangasem Muhammadiyah, and IBS of Modern Muhammadiyah have values of self-sacrifice, unity, respect, cooperation, and value of pride in being a nation.

The religious tolerance and nationalism values that have been taught in each IBS refers to the spirit of jihad for the benefit of religion and nation. In this sense; the researchers arise the concept of 'Jihad Kebhinekaan' (Jihad of diversity) based on what was found by the researchers about several theories with the results of observation that occur in the IBS. According to Yusuf al- Qaradawi, Jihad is derived from the word jahada-yujahidu-jihad-mujahadan, (Al-Qaradhawi, 2011a) that refers to expressing effort of deploying ability, potential and strength, or bearing difficult things. Meanwhile, kebhinekaan means diversity. Indonesia with diverse culture, religion, ethnicity, race, language and group leads to multicultural society. Jihad kebhinekaan is a form of religious and nation interests to realize the benefit of nation and state in the unity of Bhineka Tunggal Ika.

Jihad kebhinekaan is a means of the epistemology of contemporary Islamic science that borrows Yusuf Al-Qaradhawi's perspective in the book of Ringkasan Fikih Jihad, M. Abed al Jabiri textually-bayani through the book of Fikih Kebhinekaan or the tafsir study and classical Fiqh as well as textual meaning, and M. Quraish Shihab's perspective. Here are the efforts of Jihad kebhinekaan implemented:

\section{Jihad in Knowledge}

Jihad implemented in the field of knowledge refers to the apportionment of forming the nation's strength with scientific and practical realms. (Al-Qaradhawi, 2011b) Allah SWT mentions in the surah At Taubah verse 122 that means: "And it is not for the believers to go forth (to battle) all at once. For there should separate from every division of them a group (remaining) to obtain understanding in the religion and warn their people when they return to them that they might be cautious" (Departemen Agama RI, 1989a) Based on the verse, jihad is not only done in war, but also in seeking knowledge which is a part of jihad against stupidity.

The nation resurgence can be implemented through liberation from stupidity and stunted mental (Gunawan et al, 2015a) that the nation must have a clear direction of life, otherwise, the nation would be a slave by certain parties who want to take advantage and is not easily influenced by other nations. The knowledge can be obtained from the teacher scientifically and the practice can be through life experience. The knowledge taught in the IBS, particularly in this study, all parties of IBS of Islam Al-Islam, IBS of Karangasem Muhammadiyah, IBS of Sunan Drajat, and IBS of Modern Muhammadiyah combine the public and religious knowledge in the purpose of educating nation's children as a part of jihad in the field of knowledge.

\section{Jihad in Social}

Jihad in the field of social relates to the protection of the family including parents, children and siblings. In history, Al-Bukhari and Muslims from Abdullah bin Amr bin Al-Ash, stated, 'A man came to the Prophet Muhammad in order to ask permission to do Jihad. Then Rasulullah SAW said, 
'Are your parents still alive?' The man answered, 'Yes.' Rasulullah SAW said, 'then do Jihad for both of your parents.' (Al-Qaradhawi, 2011c) In another hadith, it is also narrated that the Prophet Muhammad SAW once said; "The best of you is the defender of the family during (its defence) does not lead to sin." (Narrated by Abu Daud). (Shihab, 2020)

Based on the history of the hadith above, it can be concluded that the family lives in Islamic teachings also reflects a unity built up based on tribe, nation, or humanity in a way of defending and fighting for the truth. If Yusuf al- Qaradawi stated that jihad in society includes families, children and siblings (in the context of each individual's family), on the other hand, it is different from the subject of jihad in society according to M. Quraish Shihab that it is showed to the relations among Indonesian with its social issues. Principally, M. Quraish Shihab stated that jihad in social is covered in Surah Al-Ma'un verses 1-6. (Aziz \& Abidin, 2017) The issue, according to M. Quraish Shihab covers all social issues related to poverty, moral crises, stupidity, crime and so on which are the act of jihad to overcome social issues.

In the context of this study, jihad in the field of social for IBS of Islam Al-Islam, IBS of Karangasem Muhammadiyah, IBS of Sunan Drajat, and IBS of Modern Muhammadiyah is an understanding that should be taught to the santri, that it can be done through the protection of the family and relations of human beings. Especially in everyday life, the santri's provide supports to one another and protect the IBS's reputation with good manners.

\section{Jihad in Economy}

Jihad in the field of economy is a jihad to seek a livelihood in order to meet life's needs. Ka'ab bin Ujrah said, "A man passed by Prophet Muhammad and the Companions of the Prophet saw the tenacity of that man when working. The Companions said to the Prophet, 'O Rasulullah, hope that man's doing included jihad in Allah's way!' The Prophet SAW said, 'When he went working for his little son, then he did jihad in Allah's way! If he went working for his elderly, then he did jihad in Allah's way! If he went working to meet his own's needs, then he did jihad in Allah's way! But if he went working to show off and be proud of himself, then he did jihad in Satan's way." (Al-Qaradhawi, 2011d) Islamic religion teaches a positive working ethically, with this Islamic majority population in Indonesia, there should be an economic increase started from Indonesian youths to work independently and creatively.

Qur'an mentioned about 50 times about the command to work, for example, "Say, 'Each works according to his manner" (QS: 17: 84), "So when thou art empty, labour" (Surah: 94:17) (Gunawan et al, 2015b) Some of these verses are about commands to work, so that religious encouragement and economic activities are able to unite to end the story of poverty in Indonesia.

Indonesia is its rich nature and culture, certainly, the non-indigenous interests cannot be allowed to dominate. As a nation, Indonesia must be able to overcome its economy, with its condition of a multicultural nation that is used to cooperating to overcome the global economic crisis and be able to compete with other developed countries. In conclusion, through jihad in the economy, starting with changes of mindset in relation to the importance of working ethic, opening jobs, not being tempted by the corruption act, and no social gap, then Indonesia is no more left behind by other countries.

Jihad in the field of economy, in the results of this study, was found that IBS Sunan Drajat made business to improve IBS's welfare through; Ocean Salt Production, Sawmill, CV. Aidrat, Department Store, CV. Mustika Toko Bangunan, Canteen, and PT. SDL. (Hasan, personal communication, August 4, 2020) By this under the auspices of IBS of Sunan Drajat, the santri participate in the business as to train the independence and the spirit of entrepreneurship. Therefore, the IBS also participates in the development of the Indonesian economy.

While in IBS of Islam Al-Islam, IBS of Karangasem Muhammadiyah, and IBS of Modern Muhammadiyah can be seen from the business, such as canteens located around the IBS, in order to support IBS's economy, and the santri are also involved in the business to be assigned to keep the 
canteen, so that they are directly doing jihad in the field of economy, and possess the character of working ethic that will be used in the society.

Jihad in Education

Jihad in the field of education refers to one founding schools or IBS that teach students to have a love for religion, race and country so that they do not act excessively at those things mentioned (Al-Qaradhawi, 2011e). Every person has the same opportunity to enter the world of education. Education should not lead to strengthening social segregation (Gunawan et al, 2015c), all schools must be accessible by anyone with any background of religion and ethnicity and be able to preserve Indonesian culture. Education is very important for the Muslims' civilization and the development of a country. With the spirit and awareness of each individual, backwardness due to education will not let the nation experience stupidity and poverty. Since the poverty factor, one of which is due to poor human resources.

Concerning the study, the efforts of jihad in education done by PPIA (IBS of Islam Al-Islam) was found to have Tsanawiyah as formal education and diniyah as religious education. Meanwhile, in PPSD (IBS of Sunan Drajat), PPKM (IBS of Karangasem Muhammadiyah), and PPMM (IBS of Modern Muhammadiyah) were found through establishing educational facilities ranging from PAUD to university level. Those educational facilities by all four IBS are an example of jihad in the field of education to improve educational quality and educate the nation.

\section{Jihad in Health}

Jihad in the field of health is done by building hospitals or health facilities to provide treatment to the unhealthy and to improve social health. (Al-Qaradhawi, 2011e) Health is the most important state for all humans, that they can perform worships or any activities quietly and easily with such healthy body. This study revealed jihad in the field of health were performed by IBS of Sunan Drajat, IBS of Karangasem Muhammadiyah, and IBS of Modern Muhammadiyah through providing health facilities, such as a clinic located around IBS for the unhealthy santri in order to have capable health service. Besides, the IBS of Karangasem Muhammadiyah has built a hospital called 'RS Abdurrahman Syamsyuri' for society in general as a means of health facilities.

\section{Jihad in Environment}

Jihad in the field of environment is done by maintaining and protecting the environment from any pollutions, damages and other dangers. (Al-Qaradhawi, 2011f) All that is created by Allah on this earth, both creature and environment have mutual regard. If either of them is disturbed, then another creature in the same environment is also disturbed (Shihab, 1996). There are a lot of occurrences of destroying the environment or nature by humans due to their desires (exploitative) and lacking concern to the environment affecting environmental damage or natural disasters, such as flood, ecosystems destruction, forest fire, landslides, air pollution and so on.

Whereas Islam teaches to preserve nature as in surah al Baqarah verse 205 which means: "When he leaves, he sets out to spread corruption in the land, destroying crops and live-stock, God does not like corruption". This verse explains the prohibition to destroy nature because the Muslims essentially have to keep it as a form of accountability of 'Khalifah' on this earth. The IBS also teaches to maintain the environment, as observed in this study that the centres work together, using ro'an (cooperation) as a form of it. The habit of throwing rubbish in its place is also an effort to maintain or protect the environment.

The conclusion of the concept of Jihad Kebhinekaan is as an earnest effort with all abilities, potentials and strengths to realize the benefit of religious society, nation and state in the unity of 'Bhineka Tunggal Ika'. In the context of this study, based on research findings and theory synchronization factors in the manifestation of nationalism, and the understanding of jihad, it is relevant to the recent condition that those efforts are a part of hubbul wathan minal iman. 


\section{CONCLUSION}

The implications of the religious tolerance at IBS of Islam Al-Islam, IBS of Karangasem Muhammadiyah, IBS of Sunan Drajat and IBS of Modern Muhammadiyah possess values of acceptance, respect, patience, freedom and cooperation. Meanwhile, differences are found dealing with nationalism values, where IBS of Islam Al-Islam merely possesses a value of respect. In contrast, IBS of Sunan Drajat, IBS of Karangasem Muhammadiyah, and IBS of Modern Muhammadiyah possess values of self-sacrifice, unity, respect, cooperation, and value of pride in being a nation. From the results of religious tolerance and nationalism values taught, each IBS has the spirit of jihad for the benefit of religion and nation. The researchers arise the concept of 'Jihad Kebhinekaan' (Jihad of diversity) based on research findings factors. In addition, here are the efforts of Jihad kebhinekaan implemented: Jihad in knowledge, Jihad in social, Jihad in the economy, Jihad in education, Jihad in health, and Jihad in the environment. Then, this jihad kebhinekaan underlies the realization of religious tolerance and nationalism values in each IBS.

\section{REFERENCES}

Al-Qaradhawi, Y. (2011a). Ringkasan Fikih Jihad. Jakarta: Pustaka Al-Kausar Al-Qaradhawi, Y. (2011b). Ringkasan Fikih Jihad. Jakarta: Pustaka Al-Kausar Al-Qaradhawi, Y. (2011c). Ringkasan Fikih Jihad. Jakarta: Pustaka Al-Kausar Al-Qaradhawi, Y. (2011d). Ringkasan Fikih Jihad. Jakarta: Pustaka Al-Kausar Al-Qaradhawi, Y. (2011e). Ringkasan Fikih Jihad. Jakarta: Pustaka Al-Kausar Al-Qaradhawi, Y. (2011f). Ringkasan Fikih Jihad. Jakarta: Pustaka Al-Kausar Arikunto, S. (2005). Prosedur Penelitian. Jakarta: Renika Cipta

Aziz \& Abidin. (2017). Tafsir Moderat Konsep Jihad Dalam Perspektif M. Quraish Shihab.

Kontemplasi: Jurnal Ilmu-Ilmu Ushuluddin, 5(2), 1-24.

https://doi.org/10.21274/kontem.2017.5.2.461-484

Baidi, B. (2012). Toleransi Terhadap Umat Kristiani Ditinjau Dari Fundamentalisme Agama Dan Kontrol Diri: Studi Pada Jamaah Majelis Taklim Di Kota Semarang. (Semarang: Unpublished Thesis, IAIN Walisongo Semarang

Departemen Agama RI. (1989a). Al-Qur'an dan Terjemahannya. Surabaya: Mahkota

Departemen Agama RI. (1989b). Al-Qur'an dan Terjemahnya. Surabaya: Mahkota

Departemen Agama RI. (1989c). Al-Qur'an dan Terjemahnya. Surabaya: Mahkota

Faisal, S. (1990). Penelitian Kualitatif: Dasar-Dasar dan Aplikasi. Malang: YA3

Ghofur, A. W. (2005). Tafsir Sosial. Yogyakarta: eLSAQ Press

Gunawan et al. (2015a). Fikih Kebhinekaan Pandangan Islam Indonesia Tentang Umat, Kewarganegaraan, dan Kepemimpinan Non-Muslim.

Gunawan et al. (2015b). Fikih Kebhinekaan Pandangan Islam Indonesia Tentang Umat, Kewarganegaraan, dan Kepemimpinan Non-Muslim.

Gunawan et al. (2015c). Fikih Kebhinekaan Pandangan Islam Indonesia Tentang Umat, Kewarganegaraan, dan Kepemimpinan Non-Muslim.

In'amuzzahidin, M. (2017). Konsep Kebebasan Dalam Islam. At-Taqaddum, 7(2), 259. https://doi.org/10.21580/at.v7i2.1206

Ismail, F. (2014). Dinamika Kerukunan Antarumat Beragama. Bandung: Rosdakarya

Jempa, N. (2018). Nilai-Nilai Agama Islam. Jurnal Pedagogik, 1(2), 101-112. https://ejournal.unmuh.ac.id/index.php/pedagogik/article/download/564/44.

Khisbiyah. (2007). Menepis Prasangka, Memupuk Toleransi untuk Multikulturalisme: Dukungan dari Psikologi Sosial. Surakarta: PSB-PS UMS

Kurnia, R. (2011). Akhlak Mulia: Menjadi Dirimu Yang Terbaik. Jakarta: Imperial Bhakti Utama

Mandarinnawa, N. K. (2016). Pengaruh Tingkat Toleransi Beragama Terhadap Interaksi Sosial Peserta Didik Kelas Xi Di Smk Negeri 7 Semarang Tahun Ajaran 2015/2016. (Semarang: Unpublished Thesis, Universitas Islam Negeri Walisongo Semarang

Moeljono, D. (1989a). Jiwa Semangat dan Nilai-Nilai Perjuangan Bangsa Indonesia. Semarang: IKIP Press

Moeljono, D. (1989b). Jiwa Semangat dan Nilai-Nilai Perjuangan Bangsa Indonesia. Semarang: IKIP Press

Mulyana, R. (2011a). Mengartikulasikan Pendidikan Nilai. Bandung: Alfabeta 
Mulyana, R. (2011b). Mengartikulasikan Pendidikan Nilai. Bandung: Alfabeta

Mustofa, I. (2019). Pendidikan Nilai di Pesantren: Studi tentang Internalisasi Pancajiwa di Pondok Modern Darussalam Gontor Ponorogo. (Surabaya: Unpublished Disertation, Universitas Islam Negeri Sunan Ampel Surabaya.

Nawawi, S. R. at. (2011). Kepribadian Qur"ani. Jakarta: Amzah

Nurkholis. (2013). Pendidikan Dalam Upaya Memajukan Teknologi. Jurnal Kependidikan, 1(1), 2444. http://ejournal.iainpurwokerto.ac.id/index.php/jurnalkependidikan/article/view/530

Prasetyo, A., \& Sumardjoko, B. (2017). Penanaman Nilai-Nilai Kebangsaan di Pondok Pesantren Khalafiyah (Studi Kasus di Pondok Pesantren Al Huda Doglo Candigatak Cepogo Boyolali Tahun 2016). Vidya Karya, 31(1). https://doi.org/10.20527/jvk.v31i1.3969

Rachman, M. B. (2004). Islam Pluralis: Wacana Kesetaraan Kaum Beriman. Jakarta: Raja Grafindo Utama

Rachman, M. B. (2010). Reorientasi Pembaruan Islam. Jakarta: Lembaga Studi Agama dan Filsafat

Rachman, M. B. (2012). Argumen Islam Untuk Liberalisme. Jakarta: Grasindo

Rachman, M. B. (2015). Pendidikan Karakter: Pendidikan Menghidupkan Nilai untuk Pesantren, Madrasah, dan Sekolah. Jakarta: Lembaga Sosial Agama dan Filsafat (LSAF)

Rini, M. T. (2019). Hubungan Antara Kecerdasan Interpersonal Dengan Sikap Toleransi Beragama Pada Peserta Didik Kelas X SMA Negeri 3 Yogyakarta. (Yogyakarta: Unpublished Thesis, Universitas Muhammadiyah Yogyakarta

Rois, N. (2017). Progress. Jurnal Pendidikan Agama Islam, o5(1), 1-29.

Rusdiana, Z. (2014a). Pendidikan Nilai Kajian Teori dan Praktik di Sekolah. Bandung: Pustaka Setia

Rusdiana, Z. (2014b). Pendidikan Nilai Kajian Teori dan Praktik di Sekolah. Bandung: Pustaka Setia

Ruslani. (2000). Masyarakat Dialog antar Agama; Studi atas Pemikiran Muhammad Arkoun. Yogyakarta: Yayasan Bintang BudayaS

Shihab, M. Q. (1996). Islam, Kependudukan dan Lingkungan Hidup dalam Membumikan AlQur'an. Bandung: Mizan

Shihab, M. Q. (2020). Islam \& Kebangsaan Tauhid Kemanusiaan, dan Kewarganegaraan. Tanggerang: Lentera Hati

Sholikin, A. (2018). Potret Sikap Radikalisme Menuju Pada Perilaku Terorisme Di Kabupaten Lamongan. Journal of Governance, 3(2). https://doi.org/10.31506/jog.v3i2.3255

Sugiyono. (2016). Metode Penelitian Pendidikan Pendekatan Kuantitatif, Kualitatif dan R\&D. Bandung: Alfabeta 